\title{
FASAKH PERKAWINAN KARENA ISTRI MENGALAMI GANGGUAN JIWA: STUDI KASUS PUTUSAN PENGADILAN AGAMA PATI No. 1899/Pdt.G/2013/PA.Pt.
}

\author{
Iis Linawati, Dian Septiandani, Efi Yulistyowati
}

Fakultas Hukum Universitas Semarang

iislinawati7@gmail.com.dian_septiandani@gmail.com, efiyulistyowati@gmail.com

\begin{abstract}
ABSTRAK
Penelitian ini menganalisis tentang fasakh perkawinan dalam Putusan Nomor 1899/Pdt.G/2013/PA.Pt. dan dasar pertimbangan Hakim dalam Putusan Nomor 1899/Pdt.G/2013/PA.Pt dalam mem-fasakh-kan perkawinan. Jenis/tipe penelitian yang digunakan adalah penelitian hukum normatif/doktrinal, spesifikasi penelitian deskriptif analitis, metode pengumpulan data menggunakan data sekunder yang diperoleh dari bahan hukum primer dan bahan hukum sekunder yang dianalisis secara normatif kualitatif. Berdasarkan hasil penelitian fasakh perkawinan dalam Putusan Pengadilan Agama Pati Nomor 1899/Pdt.G/2013/ PA.Pt, alasan Pemohon mengajukan permohonan fasakh terhadap Termohon karena Termohon mengalami gangguan jiwa atau stres termasuk ke dalam alasan-alasan perceraian. Dalam pembuktian cacat badan atau penyakit yang ada pada Termohon, Majelis Hakim hanya berdasarkan pada saksi-saksi yang dihadirkan Pemohon, tanpa adanya alat bukti pendukung lain seperti surat keterangan dari Rumah Sakit Jiwa dan Majelis Hakim dalam mem-fasakh-kan perkawinan karena rumah tangga Pemohon dan Termohon sudah tidak harmonis dan sudah tidak mencapai tujuan perkawinan sebagaimana Pasal 1 Undang-Undang Nomor 1 Tahun 1974 juncto Al-Qur'an surat Ar-Rum ayat 21, dan telah terdapat alasan bercerai sebagaimana dimaksud dalam Pasal 19 huruf (e) PP Nomor 9 Tahun 1975 juncto Pasal 116 huruf (e) Kompilasi Hukum Islam, dan Pemohon dapat membuktikan dalil-dalil permohonannya dan permohonan Pemohon tidak melawan hukum. Dasar pertimbangan Hakim dalam mem-fasakh-kan perkawinan antara Pemohon dan Termohon berdasar pada dasar faktual, dasar hukum dan Majelis Hakim sependapat dan mengambil alih pendapat ahli fiqh.
\end{abstract}

Kata kunci: Perkawinan; fasakh; gangguan jiwa;Pengadilan Agama;

ABSTRACT

This research analyzed about fasakh marriage in court rulling 1899/Pdt.G/2013/PA.Pt and the basis of judge's consideration in court rulling Number 1899/Pdt.G/2013/PA.Pt in making fasakh marriage.Type of research used is normative/doctrinal,specification of descriptive analitycal research, Data collection method using secondary data, obtained from primary legal materials and secondary law material which then analyzed normatively qualitative.Based on the result of research fasakh mariage in court rylling of religion court of Pati Number 1899/Pdt.G/2013/PA.Pt.the reasons of the Petitioners filed a petition for the fasakh against the Respondent because the Respondent suffered a mental or mental disordersincluding the reasons for divorce.In the proof of disability or disease existing in the Respondent, the Panel of Justices is based only on the witnesses presented by the Petitioner, without any other supporting evidence such as a letter from thepsychiatric hospitaland the Panel of Judges in making the fasakh because the Applicant and the Respondent's household have been out of harmony and have not achieved the purpose of marriage as Article lof Law Number 1 Year 1974 juncto Al-Qur'an letter ArRum verse 21, and there have been reasons for divorce as referred to in Article 19 letter (e) of Government Regulation Number 9 Year 1975 juncto Article 116 letter (e) Compilation of Islamic Law, and the Petitioner may prove the arguments of his petition and the Petitioners' petition is not against the lawThe basis of judge's consideration in making the fasakh marriage between the Petitioners and the Respondent based on the factual basis, the legal basis and the Panel of Judges agree and take over the opinion of the fiqh experts.

Keywords: marriage; fasakh; mental disorders; religion court 


\section{A. Pendahuluan}

Perkawinan merupakan sesuatu yang didambakan bagi seorang laki-laki maupun perempuan dengan tujuan untuk membentuk keluarga yang kekal dan bahagia yang bertujuan untuk memperoleh keturunan. Manusia diciptakan oleh Allah SWT secara berpasang-pasangan, firman Allah SWT dalam QS. An Nur (24) : 32 yang artinya “..... dan kawinkanlah orang-orang yang sendirian di antara kamu, dan orang-orang yang patut (kawin) dari hamba-hamba sahayamu yang perempuan. Jika mereka miskin, (maka) Allah akan memampukan mereka dengan karunia-Nya dan Allah Maha luas (pemberian-Nya), lagi Maha Mengetahui.” Dalam Undang-Undang Nomor 1 Tahun 1974 tentang Perkawinan, bab 1 dasar hukum perkawinan Pasal 1: perkawinan adalah ikatan lahir batin antara seorang pria dengan seorang wanita sebagai suami istri dengan tujuan membentuk keluarga atau rumah tangga yang bahagia dan kekal berdasarkan Ketuhanan Yang Maha Esa. Menurut Kompilasi Hukum Islam Pasal 2, perkawinan menurut hukum Islam adalah pernikahan, yaitu akad yang sangat kuat atau mitsaaqon ghalidzan untuk menaati perintah Allah dan melaksanakannya merupakan ibadah. tetapi pada kenyataannya tidak semua perkawinan yeng telah terjadi mencapai tujuan perkawinan sebagaimana yang dimaksud diatas, kadangkala dalam suatu rumah tangga terjadi percekcokan atau perselisihan diantara keduanya, atau sebab-sebab lain misalnya setelah terjadi perkawinan ternyata suami atau istri tersebut mengalami gangguan jiwa atau stres, sehingga pada akhirnya harus berakhir dengan putusnya perkawinan sebagai contoh pada Putusan Pengadilan Agama Pati Nomor 1899/Pdt.G/2013/PA.Pt. dalam perkara permohonan fasakh nikah yang diajukan oleh Pemohon yang merupakan suami dari Termohon mengajukan permohonan fasakh ke Pengadilan Agama Pati terhadap Termohon dikarenakan setelah perkawinan berlangsung \pm 1 hari Pemohon baru mengetahui bahwa ternyata Termohon mengalami gangguan jiwa atau stres, sehingga Majelis Hakim mengabulkan permohonan Pemohon dengan seluruhnya.

\section{B. Perumusan Masalah}

1. Bagaimana fasakh perkawinan dalam Putusan Nomor 1899/Pdt.G/2013/ PA.Pt di Pengadilan Agama Pati?

2. Apa dasar pertimbangan Hakim dalam Putusan Nomor 1899/Pdt.G/2013/ PA.Pt dalam memfasakhkan perkawinan?

\section{Tujuan dan Manfaan Penelitian}

\section{Tujuan Penelitian}

1. Untuk mengetahui fasakh perkawinan dalam Putusan Nomor 1899/Pdt.G /2013/PA.Pt di Pengadilan Agama Pati.

2. Untuk mengetahui dasar pertimbangan Hakim dalam Putusan Nomor 1899/Pdt.G/2013/PA.Pt dalam memfasakhkan perkawinan. 


\section{Manfaat Penelitian}

a. Manfaat Teoritis :

Hasil penelitian ini diharapkan dapat bermanfaat bagi pengembangan ilmu hukum khususnya Hukum Perdata mengenai fasakh perkawinan karena istri mengalami gangguan jiwa.

b. Manfaat praktis :

Hasil penelitian ini diharapkan dapat bermanfaat bagi :

1) Bagi Akademisi: sebagai rujukan dan informasi ilmiah dalam melakukan penelitian dan pendalaman mengenai fasakh perkawinan.

2) Bagi Masyarakat: agar masyarakat mengetahui bagaimana fasakh perkawinan dalam Putusan Nomor 1899/Pdt.G/2013/PA.Pt di Pengadilan Agama Pati dan dasar pertimbangan Hakim dalam Putusan Nomor 1899/Pdt.G/2013/PA.Pt dalam memfasakhkan perkawinan.

\section{Tinjauan Pustaka}

\section{Tinjauan Umum tentang Perkawinan}

\section{a. Pengertian Perkawinan}

Perkawinan adalah suatu ikatan lahir dan batin antara seorang pria dengan wanita sebagai suami isteri dengan tujuan untuk membentuk suatu keluarga atau rumah tangga yang bahagia dan kekal berdasarkan Ketuhanan Yang Maha Esa, yang harus dilaksanakan sesuai agamanya masing-masing, dan juga harus dicatat menurut peraturan perundang-undangan yang berlaku. ${ }^{1}$ perkawinan merupakan ikatan lahir batin antara seorang pria dan wanita untuk membentuk keluarga yang bahagia dan kekal. Perkawinan menurut Hukum Islam adalah pernikahan, yaitu akad yang sangat kuat atau mitsaqan ghalizhan untuk menaati perintah Allah dan melaksanakannya merupakan ibadah. ${ }^{2}$

\section{b. Asas-Asas Perkawinan}

Adapun yang menjadi asas-asas dari hukum perkawinan di Indonesia adalah sebagai berikut:

a. Tujuan perkawinan adalah untuk membenuk keluarga bahagia dan kekal

b. Perkawinan dilakukan menurut agama dan kepercayaan masing-masing. Dengan demikian, perkawinan tidak sah menurut hukum negara jika perkawinan tersebut tidak sah jika ditinjau menurut agama dan kepercayaan masing-masing orang yang hendak kawin tersebut.

c. Pada prinsipnya berlaku asas monogami. Artinya oleh hukum yang berlaku di Indonesia, seorang suami hanya diperkenankan mengawini seorang istri saja, jadi tidak boleh memiliki lebih dari satu istri pada waktu yang bersamaan. Kekecualian terhadap berlakunya asas monogami ini dibuka oleh Undang-Undang asalkan memenuhi syarat-syarat tertentu,

\footnotetext{
${ }^{1}$ Munir Fuady, Konsep Hukum Perdata (Jakarta: Rajawali Pers, 2014), halaman 10.

${ }^{2}$ Amir Syarifuddin, Hukum Perkawinan Islam di Indonesia: Antara Fiqh Munakahat dan Undang-Undang Perkawinan (Jakarta: Kencana, 2006), halaman 40.
} 
termasuk syarat persetujuan dari isteri yang sudah ada, dan sesuai pula dengan agama yang dianut.

d. Untuk boleh melakukan perkawinan, Undang-Undang mensyaratkan kematangan jiwa dan raga dari calon mempelai. Karenanya Undang-Undang memperbolehkan dilangsungkannya perkawinan setelah calon pengantin menjadi dewasa, yakni sudah berumur 19 tahun bagi pria dan 16 tahun bagi wanita.

e. Perceraian dipersulit karena Undang-Undang menganggap bahwa tujuan perkawinan bukan untuk bercerai, tetapi untuk membentuk keluarga yang bahagia dan kekal abadi

f. Berlaku prinsip emansipasi antara suami dan isteri, sehingga kedudukan isteri maupun suami adalah seimbang baik itu dalam rumah tangga maupun dalam masyarakat.

g. Perkawinan tidak dipersulit. Karena itu, keterlibatan Pengadilan dalam proses perceraian adalah hanya sekedar untuk menjamin terlaksananya unsur kepastian hukum dan keadilan bagi pihak suami maupun pihak isteri. Dan syarat kecukupan umur atau dewasa untuk boleh kawin juga bukan untuk mempersulit pelaksanaan perkawinan, melainkan hanya untuk menjamin agar perkawinan dapat menjamin kebahagiaan dan kekekalan. ${ }^{3}$

\section{c. Rukun dan Syarat Perkawinan}

Adapun rukun secara lengkap yaitu:

a. calon mempelai laki-laki

b. calon mempelai perempuan

c. wali dari mempelai perempuan yang akan mengadakan perkawinan

d. dua orang saksi

e. ijab yang dilakukan oleh wali dan qabul yang dilakukan oleh suami ${ }^{4}$

Syarat sahnya perkawinan yaitu adanya mahar. Para ulama telah menetapkan bahwa mahar itu hukumnya wajib berdasarkan Al-Qur'an, sunah dan ijmak. Mahar oleh para ulama ditempatkan sebagai syarat sahnya nikah seperti yang dijelaskan oleh Ibn Rusyd didalam bidayah AlMujtahidnya. $^{5}$

\section{Tinjauan tentang Putusnya Perkawinan}

\section{a. Putusnya Perkawinan menurut Undang-Undang Nomor 1 Tahun 1974 tentang}

\section{Perkawinan.}

Dalam Undang-Undang Nomor 1 Tahun 1974, Pasal 38: perkawinan dapat putus karena: a. Kematian b. Perceraian c. Atas keputusan Pengadilan.

1) Kematian

Kematian disini yaitu apabila salah satu pihak baik suami ataupun istri meninggal dunia/mati maka putuslah hubungan perkawinan itu.

${ }^{3}$ Fuady, op.cit., halaman 10-11.

${ }_{5}^{4}$ Syarifuddin, op.cit., halaman 61 .

${ }^{5}$ Amiur Nuruddin dan Azhari Akmal Tarigan, Hukum Perdata Islam di Indonesia: Studi Kritis Perkembangan Hukum Islam dari Fikih, UU No.1/1974 Sampai KHI (Jakarta: Kencana, 2004), halaman 65. 
2) Perceraian

Dalam Pasal 39, Undang-Undang Nomor 1 Tahun 1974:

(1) Perceraian hanya dapat dilakukan di depan sidang Pengadilan setelah Pengadilan yang bersangkutan berusaha dan tidak berhasil mendamaikan kedua belah pihak.

(2) Untuk melakukan perceraian harus ada cukup alasan bahwa antara suami istri itu tidak akan dapat rukun sebagai suami isteri.

(3) Tata cara perceraian di depan sidang Pengadilan diatur dalam peraturan perundangan tersebut.

3) Putusan pengadilan

Putusnya perkawinan karena atas keputusan Pengadilan adalah putusnya ikatan perkawinan yang disebabkan adanya gugatan perceraian seorang istri yang melangsungkan perkawinan menurut agama Islam atau yang disebabkan adanya gugatan perceraian seorang suami atau seorang istri yang melangsung kan perkawinannya menurut agamanya dan kepercayaannya itu selain agama Islam yang dinamakan cerai gugat. ${ }^{6}$

\section{b. Putusnya Perkawinan Menurut Hukum Islam}

Putusnya Perkawinan Menurut Hukum Islam antara lain:

a) Thalak

Secara harfiyah thalak itu berarti lepas dan bebas. Dihubungkannya kata thalak dalam arti kata ini dengan putusnya perkawinan karena antara suami dan istri sudah lepas hubungannya atau masing-masing sudah bebas. ${ }^{7}$

b) Khulu'

Khulu' atau talaq tebus menurut Soemiyati ialah bentuk perceraian atas persetujuan suami istri dengan jatuhnya talak satu dari suami kepada istri dengan tebusan harta atau uang dari pihak istri yang menginginkan cerai dengan khulu' $^{\prime}$ tu. $^{8}$

c) Syiqaq

Soemiyati menjelasakan bahwa syiqaq itu brarti perselisihan atau menurut istilah fiqh brarti perselisihan suami istri yang diselesaikan dua orang hakam, satu orang dari pihak suami dan satu orang dari pihak istri. ${ }^{9}$

d) Fasakh

Secara etimologis,Fasakh berarti membatalkan. Apabila dihubungkan dengan perkawinan fasakh berarti membatalkan perkawinan atau merusakkan perkawinan. ${ }^{10}$

${ }^{6}$ Rachmadi Usman, Aspek-Aspek Hukum Perorangan \& Kekeluargaan di Indonesia (Jakarta: Sinar Grafika, 2006), halaman 402.

${ }^{7}$ Syarifuddin, op.cit., halaman 198.

${ }^{8}$ Muhammad Syaifuddin, Sri Turatmiyah, dan Annalisa Yahanan, Hukum Perceraian(Jakarta:Sinar Grafika, 2014), halaman 131.

${ }^{9}$ Ibid., halaman 129.

${ }^{10}$ Ibid., halaman 137. 
e) Ta'lik Talak

Pada prinsipnya ta'liq talak, menurut penjelasan Sudarsono, adalah suatu penggantungan terjadinya jatuhnya talak terhadap peristiwa tertentu sesuai dengan perjanjian yang telah dibuat sebelumnya antara suami istri. ${ }^{11}$

f) Ila

Ila berasal dari bahasa Arabyang secara arti kata berarti "tidak mau melakukan sesuatu dengan cara bersumpah atau sumpah. ${ }^{12}$

g) Zhihar

Zhihar adalah prosedur talak yang hampir sama dengan Ila'. Arti zhihar ialah seorang suami yang bersumpah bahwa istrinya itu baginya sama dengan punggung istrinya. ${ }^{13}$

h) Li'aan

Sumpah suami yang menuduh istrinya berbuat zina, sedangkan dia tidak mampu medatangkan empat orang saksi. ${ }^{14}$

i) Kematian

Apabila salah satu diantara mereka meninggal/mati, baik itu suami atau istri maka mengakibatkan perkawinan itu putus.

\section{Tinjauan tentang Fasakh}

\section{a. Pengertian Fasakh}

Fasakh berasal dari bahasa Arab dari akar kata fa-sa-kha yang secara etimologi berarti membatalkan. Bila dihubungkan kata ini dengan perkawinan berarti membatalkan perkawinan atau merusak perkawinan. Dalam arti terminologis ditemukan beberapa rumusan yang hampir bersamaan, maksudnya diantaranya yang terdapat dalam KBBI, berikut: pembatalan ikatan pernikahan oleh Pengadilan Agama berdasarkan tuntutan istri atau suami yang dapat dibenarkan Pengadilan Agama atau karena pernikahan yang telah terlanjur menyalahi hukum pernikahan. ${ }^{15}$

Menurut Hasbullah Bakry, Fasakh adalah perceraian yang diselenggarakan oleh Hakim berdasarkan atas sebab-sebab yang telah ditetapkan oleh syari'ah salah satu suami/isteri sakit gila, sopak (belang), sakit kusta (lepro). Suami innin (tidak kuasa bersetubuh) suami miskin, tidak kuasa memberi makan, pakaian atau tempat kediaman kepada isterinya (seperti telah ditetapkan pada syari'ah) fasakh dapat juga diminta apabila pernikahan sudah dijanjikan bahwa mempelai laki-laki atau mempelai wanita harus mempenuhi syarat-syarat tertentu, umpamanya tentang keturunan atau pekerjaan kemudian ternyata tidak memenuhi syarat-syarat yang telah ditentukan itu. $^{16}$

${ }^{11}$ Ibid., halaman 141.

${ }^{12}$ Syarifuddin, op.cit., halaman 275.

${ }^{13}$ Syaifuddin,Sri Turatmiyah, dan Annalisa Yahanan,, op.cit., halaman 153

${ }^{14}$ Syarifuddin, op.cit., halaman 288

${ }^{15}$ Ibid., halaman 242.

${ }^{16}$ Ellida Wirza Desianty, “Analisis Putusan Hakim Pengadilan Agama Makassar Mengenai Fasakh Perkawinan Karena Murtad (Studi Kasus Putusan Pengadilan Agama Makassar Nomor 152/Pdt.G/2012/PA Mks)" (Skripsi Fakultas Hukum, Universitas Hasanuddin Makassar, 2013), halaman 39-40. 


\section{b. Penyebab fasakh}

Menurut Abdul Ghofur Anshori, alasan terjadinya fasakh secara umum dibedakan menjadi dua macam yaitu:

a) Perkawinan yang telah berlangsung, ternyata kemudian tidak memenuhi persyaratan yang ditentukan, baik mengenai rukun maupun syarat. Dapat juga terjadi karena keadaan bahwa pada perkawinan tersebut terdapat halangan yang membenarkan terjadinya perkawinan.

b) Fasakh terjadi karena pada diri suami atau istri terjadi sesuatu yang menyebabkan perkawinan tidak mungkin dilanjutkan, karena kalau dilanjutkan akan menyebabkan kerusakan pada suami atau istri atau keduanya, fasakh dalam bentuk ini disebut khiyar fasakh $^{17}$

Perkawinan itu bisa di fasakhkan karena ada beberapa faktor penyebab, beberapa faktor penyebab terjadinya fasakh antara lain:

1). Syiqaq

Fasakh yang terjadi karena adanya pertengkaran suami dan istri yang tidak dimungkinkan untuk didamaikan

2). Fasakh karena cacat

Yaitu cacat yang terdapat pada suami atau istri, baik cacat jasmani atau rohani

3) Fasakh karena ketidakmampuan suami memberi nafkah

Fasakh yang terjadi karena ketidak mampuan suami memberikan nafkah kepada istri maupun anak-anaknya

4)Fasakh karena suami gaib (al-mafqud)

Yang dimaksud dengan suami gaib disini adalah suami meninggalkan tempat tetapnya dan tidak diketahui kemana perginya dan dimana beradanya dalam waktu yang sudah lama. ${ }^{18}$

5)Fasakh karena melanggar perjanjian perkawinan.

Bila salah satu pihak melanggar perjanjian pihak yang dirugikan dapat mengajukan ke Pengadilan untuk putusnya perkawinan. ${ }^{19}$

\section{Tinjauan tentang Gangguan Jiwa}

Jiwa dalam ayat Al Qur'an yaitu ruh atau nafs, sedangkan gangguan jiwa itu sendiri yaitu: gangguan jiwa dikonseptualisasikan secara klinis sebagai sindrom psikologis atau pola behavioral yang terdapat pada seorang individu dan diasosiasikan dengan distress (misalnya simtom yang menyakitkan) atau disabilitas (yakni, hendaya di dalam satu atau lebih wilayah fungsi yang penting) atau diasosiasikan dengan resiko mengalami kematian, penderitaan, disabilitas, atau kehilangan kebebasan diri yang penting sifatnya, yang meningkat secara signifikan. ${ }^{20}$

${ }^{17}$ Syaifuddin,Sri Turatmiyah, dan Annalisa Yahanan,, op.cit., halaman 138.

${ }^{18}$ Syarifuddin.,op.cit., halaman 251.

${ }^{19}$ Ibid., halaman 252.

${ }^{20}$ Suhaimi, "Gangguan Jiwa Dalam Perspektif Kesehatan Mental Islam”. Jurnal RISALAH, Vol. 26, No. 4, (online),(https://media.neliti.com/media/publications/127638-ID-gangguan-jiwa-dalam-perspektif-kesehatan.pdf, diakses 10 November 2017. 


\section{E. Metode Penelitian}

\section{Metode Pendekatan}

Jenis/tipe penelitian yang digunakan adalah penelitian hukum normatif/doktrinal dengan pendekatan kasus karena penelitian ini dimaksudkan untuk menganalisis Putusan Nomor 1182/Pdt.G/2013/PA.Pt. yaitu berdasarkan data hukum primer dan bahan hukum sekunder.

\section{Spesifikasi Penelitian}

Spesifikasi penelitian yang digunakan adalah deskriptif analitis, Dalam penelitian ini menggambarkan dan menganalisis suatu objek penelitian agar diperoleh suatu gambaran tentang objek yang diteliti yaitu Putusan Nomor 1189/Pdt.G/2013/PA.Pt. sehingga penulis bisa menarik kesimpulan tentang objek yang diteliti.

\section{Metode Pengumpulan Data}

Metode pengumpulan yang digunakan adalah data sekunder.Data sekunder diperoleh dari:

a) bahan hukum primer:

1) Undang-Undang Nomor 1 Tahun 1974 tentang Perkawinan.

2) Undang-Undang Nomor 50 Tahun 2009 tentang perubahan kedua atas Undang-Undang Nomor 7 Tahun 1989 tentang Peradilan Agama.

3) Undang-Undang Nomor 18 Tahun 2014 tentang Kesehatan Jiwa.

4) Peraturan Pemerintah Nomor 9 Tahun 1975 tentang Pelaksanaan Undang-Undang Nomor 1 Tahun 1974 tentang Perkawinan.

5) Instruksi Presiden Nomor 1 Tahun 1991 Tentang Kompilasi Hukum Islam.

b) bahan hukum sekunder

Adalah data yang diperoleh dari penelitian kepustakaan atas buku-buku/ literatur, dan referensi-referensi yang relevan dengan penelitian ini.

\section{Metode Analisis Data}

Metode yang digunakan yaitu metode analisis normatif kualitatif . Penelitian yuridis normatif yang bersifat kualitatif, adalah penelitian yang mengacu pada norma hukum yang terdapat dalam peraturan perundang-undangan dan Putusan Pengadilan serta norma-norma yang hidup dan berkembang dalam masyarakat. ${ }^{21}$

\section{F. Hasil dan Pembahasan}

\section{Fasakh Perkawinan dalam Putusan Nomor 1899/Pdt.G/2013/PA.Pt.}

Alasan-alasan Pemohon mengajukan permohonan fasakh ke Pengadilan Agama Pati karena Termohon mengalami gangguan jiwa atau stres merupakan alasan-alasan perceraian yang diatur dalam Kompilasi Hukum Islam Pasal 116 huruf (e) dan Peraturan Pemerintah Nomor 9 Tahun 1975 Pasal 19 huruf (e): Perceraian dapat terjadi karena alasan atau alasan-alasan: salah satu

\footnotetext{
${ }^{21}$ Zainuddin Ali, Metode Penelitian Hukum (Jakarta: Sinar Grafika, 2010), halaman 105.
} 
pihak mendapat cacat badan atau penyakit dengan akibat tidak dapat menjalankan kewajibannya sebagai suami/isteri yang dimaksud Perceraian adalah putusnya ikatan lahir batin antara suami dan istri yang mengakibatkan berakhirnya hubungan keluarga (rumah tangga) antara suami dan istri tersebut. ${ }^{22}$ cacat badan atau penyakit adalah kekurangan yang ada pada diri suami atau istri, baik yang bersifat badaniah (misalnya cacat atau sakit tuli, buta, dan sebagainya) maupun bersifat rohaniah (misalnya cacat mental, gila, dan sebagainya ${ }^{23}$ yang mana alasan Pemohon dalam permohonannya harus dibuktikan di dalam sidang Pengadilan fasakh karena cacat ini dilakukan di hadapan Hakim Pengadilan dan tidak dapat dilakukan sendiri setelah pihak-pihak mengetahui adanya cacat tersebut. ${ }^{24}$ sedangkan didalam persidanganya Pemohon mengajukan alat bukti suratsurat meliputi fotokopi kartu identitas atas nama Sudiono dan fotokopi kutipan akta nikah dari Kantor Urusan Agama dan 2 orang saksi yang telah memberikan kesaksian yang pada pokoknya benar Termohon sejak tahun 2007 menderita sakit jiwa dan sampai sekarang belum stabil/sembuh.

Hakim Pengadilan Agama Pati berpendapat bahwa dalam suatu rumah tangga manakala suami istri telah tidak dapat menjalankan kewajibannya sebagai suami istri karena salah satu pihak mengalami luar kemampuannya seperti Termohon mengalami gangguan jiwa/stres, yang berdampak pada kehidupan rumah tangga Pemohon dan Termohon walaupun telah diusahakan perdamaian, akan tetapi tidak berhasil, maka keadaan tersebut menurut Majelis Hakim merupakan bukti rumah tangga yang berantakan, tidak harmonis lagi, dan tidak akan bisa mencapai tujuan perkawinan sebagaimana Pasal 1 Undang-Undang Nomor 1 Tahun 1974 juncto Al-Qur'an surat Ar-Rum ayat 21, karena lebih baik dibubarkan saja.

Alasan Pemohon mengajukan fasakh perkawinan ke Pengadilan Agama Pati karena rumah tangga Pemohon dan Termohon mulai tidak harmonis disebabkan karena Termohon ternyata mengalami gangguan jiwa atau stres sehingga membuat Pemohon menderita lahir dan batin, hal tersebut termasuk kedalam alasan-alasan hukum yang diatur Pasal 39 ayat 2 Undang-Undang Nomor 1 Tahun 1974 tentang Perkawinan:Untuk melakukan perceraian harus ada cukup alasan bahwa antara suami istri itu tidak akan dapat rukun sebagai suami istri yang merupakan alasanalasan perceraian. Alasan tersebut merupakan alasan yang logis mengapa Pemohon mengajukan permohonan fasakh ke Pengadilan Agama Pati, karena dalam perkawinannya sudah tidak tercapai tujuan perkawinan, perkawinan sendiri dalam Undang-Undang Nomor 1 Tahun 1974, Perkawinan adalah ikatan lahir batin antara seorang pria dan seorang wanita sebagai suami istri dengan tujuan membentuk keluarga atau rumah tangga yang bahagia dan kekal berdasarkan keTuhannan Yang Maha Esa. Berdasarkan pada alasan-alasan Pemohon mengajukan fasakh perkawinan kepada Pengadilan Agama Pati menurut Peneliti alasan tersebut sudah tepat, karena

\footnotetext{
${ }^{22}$ Syaifuddin, Sri Turatmiyah, dan Annalisa Yahanan. op.cit., halaman 18-19.

${ }^{23}$ Ibid., halaman 204.

${ }^{24}$ Ibid., halaman 206.
} 
alasan Pemohon merupakan alasan- alasan perceraian yang diperbolehkan dalam Peraturan Pemerintah Nomor 9 Tahun 1975 dan Kompilasi Hukum Islam.

Majelis Hakim dalam mem-fasakh-kan perkawinan tersebut berdasar pada Pasal 19 huruf (e) Peraturan Pemerintah Nomor 9 Tahun 1975: Perceraian dapat terjadi karena alasan atau alasanalasan: Salah satu pihak mendapat cacat badan atau penyakit dengan akibat tidak dapat menjalankan kewajibannya sebagai suami/isteri juncto Kompilasi Hukum Islam yaitu Pasal 116 huruf (e): perceraian dapat terjadi karena alasan atau alasan-alasan salah satu pihak mendapat cacat badan atau penyakit dengan akibat tidak dapat menjalankan kewajiban sebagai suami atau istri yang mana cacat badan atau penyakit itu harus dibuktikan di dalam persidangan, sedangkan di dalam persidangannya Pemohon membuktikan dalil-dalil permohonannya dengan mengajukan alat bukti surat-surat berupa Kartu Tanda Penduduk atas nama Pemohon dan Kutipan Akta Nikah dari Kantor Urusan Agama Kecamatan Dukuhseti Kabupaten Pati dan mendatangkan dua orang saksi, yaitu saksi 1 yang merupakan tetangga Pemohon dan saksi 2 yang merupakan tetangga Termohon yang telah memberikan kesaksiannya yang pada pokoknya benar bahwa Termohon sejak tahun 2007 menderita penyakit kelainan jiwa hingga sekarang belum stabil/sembuh, sehingga Majelis Hakim menemukan fakta-fakta dalam persidangan dan oleh karenanya majelis menetapkan perkawinan ini dapat difasakhkan.

Fasakh karena cacat badan atau penyakit yang ada pada diri Termohon yang mana harus dibuktikan di dalam persidangan, dalam pembuktian cacat badan atau penyakit yang ada pada diri Termohon di persidangan Majelis Hakim hanya melihat pada saksi-saksi yang dihadirkan Pemohon di dalam persidangan yang memberikan kesaksian bahwa Termohon menderita penyakit kelainan jiwa dan tidak didukung dengan alat bukti lainnya. menurut Peneliti, untuk menguatkan pembuktian kecacatan atau penyakit yang ada pada diri Termohon karena Termohon mengalami gangguan jiwa atau stres Majelis Hakim seharusnya tidak hanya berdasarkan kesaksian yang dihadirkan Pemohon tetapi Pemohon harus dapat membuktikan bahwa cacat badan atau penyakit tersebut selain dengan mendatangkan 2 orang saksi, juga dapat membuktikan dengan menggunakan alat bukti pendukung lain seperti surat keterangan dari Rumah Sakit Jiwa yang menerangkan bahwa Termohon mengalami gangguan jiwa atau stres, karena perceraian dengan alasan salah satu pihak mendapat cacat badan atau penyakit dengan akibat tidak dapat menjalankan kewajibannya sebagai suami istri maka Majelis Hakim dapat memerintahkan kepada Termohon untuk memeriksakan dirinya kedokter, sebagaimana yang terdapat dalam Pasal 75 Undang-Undang Nomor 7 Tahun 1989 tentang Peradilan Agama sebagaimana yang telah diubah dengan Undang-Undang Nomor 3 Tahun 2006 dan Undang-Undang Nomor 50 Tahun 2009: Apabila gugatan perceraian didasarkan atas alasan bahwa Tergugat mendapat cacat badan atau penyakit dengan akibat tidak dapat menjalankan kewajiban sebagai suami, maka Hakim dapat memerintahkan Tergugat untuk memeriksakan diri kepada dokter.

Karena menurut Peneliti seseorang dinyatakan mengalami gangguan jiwa atau tidak, tidak hanya sekedar melalui kesaksian-kesaksian yang dihadirkan oleh Pemohon di persidangan tetapi 
seseorang dinyatakan mengalami gangguan jiwa atau stres harus melalui pembuktian oleh orangorang yang mengetahui dengan pasti gangguan kejiwaan yang ada pada seseorang misalnya oleh dokter kejiwaan.

Majelis Hakim dalam mengabulkan permohonan Pemohon dengan mem-fasakh-kan perkawinan antara Pemohon dengan Termohon karena didalam persidangan Pemohon telah dapat membuktikan kebenaran dalil Permohonannya, sedangkan permohonan Pemohon tidak melawan hukum, sehingga permohonan Pemohon dapat dikabulkan dengan verstek

\section{Dasar Pertimbangan Hakim dalam Putusan Nomor 1899/Pdt.G/2013/PA.Pt dalam memfasakhkan perkawinan.}

Dasar pertimbangan Hakim yang pertama dalam mem-fasakh-kan perkawinan antara Pemohon dan Termohon dalam Putusan Nomor 1899/Pdt.G/2013/PA.Pt, Menurut Majelis Hakim dalam suatu rumah tangga manakala suami istri telah tidak dapat menjalankan kewajibannya sebagai suami istri karena salah satu pihak mengalami halangan diluar kemampuannya seperti Termohon mengalami gangguan jiwa atau stres, yang berdampak pada kehidupan rumah tangga Pemohon dan Termohon walaupun telah diusahakan perdamaian akan tetapi tidak berhasil, maka keadaan tersebut menurut Majelis Hakim merupakan rumah tangga yang berantakan, tidak harmonis lagi, dan tidak akan bisa mencapai tujuan perkawinan sebagaimana Pasal 1 UndangUndang Nomor 1 Tahun 1974 juncto Al-Qur'an surat Ar-Rum ayat 21, karena lebih baik dibubarkan. Dalam Pasal 1 Undang-Undang Nomor 1 Tahun 1974: Perkawinan adalah ikatan lahir batin antara seorang pria dan seorang wanita sebagai suami istri dengan tujuan membentuk keluarga atau rumah tangga yang bahagia dan kekal berdasarkan Ketuhanan Yang Maha Esa. Karena rumah tangga Pemohon dan Termohon sudah tidak sesuai dengan Pasal 1 UndangUndang Nomor 1 Tahun 1974 juncto Al-Qur'an surat Ar-Rum ayat 21, yaitu rumah tangga yang sudah tidak bahagia dan tentram sehingga atas dasar tersebut Majelis Hakim berpendapat bahwa rumah tangga Pemohon dan Termohon sebaiknya dibubarkan saja.

Pertimbangan hukum Majelis Hakim dalam mengabulkan permohonan Pemohon yaitu berdasarkan Pasal 1 Undang-Undang Nomor 1 Tahun 1974 juncto Al-Qur'an surat Ar-Rum ayat 21 menurut Peneliti sudah tepat karena Jelas bahwa didalam Undang-Undang Perkawinan dan AlQur'an surat Ar-Rum ayat 21 telah menjelaskan bahwa perkawinan itu sendiri yaitu membentuk keluarga yang bahagia dan kekal, adanya rasa tentram dan rasa kasih sayang diantara mereka.membentuk keluarga yang artinya membentuk kesatuan masyarakat kecil yang terdiri dari suami, istri dan anak-anak, yang bertujuan untuk melanjutkan keturunan dan membentuk keluarga yang bahagia, kekal, adanya rasa tentram dan kasih sayang yang merupakan suatu tujuan bersama yang ingin dicapai. Setelah perkawinan maka akan timbulah hak dan kewajiban suami istri, hak dan kewajiban suami istri sendiri telah diatur dalam Pasal 30-Pasal 34 Undang-Undang Nomor 1 
Tahun 1974 tentang Perkawinan, salah satu kewajiban seorang suami salah satunya yaitu memberi nafkah kepada keluargannya dan melindungi istrinya sebagaimana yang diatur dalam Pasal 34 ayat (1): Suami wajib melindungi isterinya dan memberikan segala sesuatu keperluan 
hidup berumah tangga sesuai dengan kemampuannya. Sedangkan kewajiban seorang istri adalah mengatur urusan rumah tangga sebaik-baiknya, sebagaimana yang terdapat dalam Pasal 34 ayat (2) Undang-Undang Nomor 1 Tahun 1974: Isteri wajib mengatur urusan rumah-tangga sebaikbaiknya. Bagaimana kewajiban suami istri itu dapat terlaksana jika salah satu diantara mereka mengalami gangguan jiwa atau stres, maka kewajiban suami istri seperti yang telah diatur dalam Undang-Undang Nomor 1 Tahun 1974 tidak akan timbul, dan dalam suatu perkawinan itu tidak adanya kebahagiaan, ketentraman dan rasa kasih sayang diantara mereka, justru didalam perkawinan tersebut membuat mereka menderita lahir dan batin. sehingga menurut Peneliti alasan tersebut patut untuk Majelis Hakim memutuskan ikatan perkawinan antara Pemohon dan Termohon melalui fasakh perkawinan.

Dasar pertimbangan Hakim dalam mem-fasakh-kan perkawinan antara Pemohon dan Termohon karena berdasar pada fakta-fakta yang didapat didalam persidangan dan telah terdapat alasan perceraian sebagaimana dimaksud dalam Kompilasi Hukum Islam Pasal 166 huruf (e) juncto Peraturan Pemerintah Nomor 9 Tahun 1975 Pasal 19 huruf (e) yaitu perceraian dapat terjadi karena alasan-alasan salah satu pihak mendapat cacat badan atau penyakit dengan akibat tidak dapat menjalankan kewajibannya sebagai suami/isteri.

Alasan-alasan Permohonan Pemohon yang merupakan alasan-alasan perceraian yaitu karena salah satu pihak mendapat cacat badan atau penyakit dengan akibat tidak dapat menjalankan kewajibannya sebagai suami istri. Pertimbangan Majelis Hakim dalam mem-fasakh-kan perkawinan antara Pemohon dan Termohon berdasarkan fakta-fakta yang didapat di persidangan yang diperoleh dari bukti-bukti yang diajukan Pemohon berupa alat bukti surat- surat yaitu Kartu Tanda Penduduk atas nama Pemohon dan kutipan Akta Nikah dari KUA, dan saksi-saksi yang dihadirkan oleh Pemohon sebagai alat bukti di persidangan yang memberikan kesaksiannya bahwa Termohon mengalami gangguan jiwa atau stres, Majelis Hakim dalam mem-fasakh-kan perkawinan antara Pemohon dan Termohon karena Termohon mengalami gangguan jiwa atau stres dalam pembuktian cacat badan atau penyakit pada diri Termohon hanya berdasarkan pada saksi-saksi yang dihadirkan oleh Pemohon, tanpa adanya alat bukti pendukung lain. Menurut Peneliti, Majelis Hakim seharusnya tidak hanya berdasarkan saksi-saksi dipersidangan, tetapi Majelis Hakim harus melihat dari alat bukti pendukung lain yang harus dibuktikan oleh Pemohon dipersidangan seperti surat keterangan dari Rumah Sakit Jiwa. Menurut Penneliti, alat bukti yang diajukan oleh Pemohon masih kurang walaupun cukup memadai dalam upaya pembuktian cacat badan atau penyakit yang ada pada Termohon.

Selain pertimbangan di atas, Majelis Hakim Pengadilan Agama Pati dalam mengabulkan permohonan fasakh dengan alasan Termohon mengalami gangguan jiwa atau stres Majelis Hakim sependapat dan mengambil alih pendapat ahli figh yang artinya: atau bilamana si isteri mendapati suaminya impotent atau gila, maka tetaplah si perempuan itu memiliki hak fasakh. Hak fasakh ini tidak hanya dimiliki oleh perempuan, tetapi laki-lakipun mempunyai hak fasakhSudarsono menjelaskan bahwa dalam syariat Islam, terutama dalam masalah munakahat 
salah satu pihak baik suami maupun istri memiliki hak untuk berinisiatif mengajukan permohonan agar ikatan pernikahan menjadi putus apabila salah satu dari keduannya merasa tertipu karena cacat. ${ }^{25}$,

Fasakh-kan perkawinan antara Pemohon dan Termohon dengan sependapat dan mengambil alih pendapat ahli figh, menurut Peneliti sudah sesuai dengan Hukum Islam yang memperbolehkan mem-fasakh-kan perkawinan karena kecacatan yang ada pada suami maupun istri karena putusnya perkawinan dalam Hukum Islam dengan cara fasakh karena salah satu diantara mereka baik istri maupun suami mengalami gangguan jiwa atau stres diperbolehkan dalam salah satu Hadits Rosul. Diriwayatkan oleh Ibnu Majah. Atsar, Umar bin Khatab pernah memfasakhan suatu perkawinan pada masa beliau menjadi khalifah karena penyakit bershak (semacam penyakit menular) dan gila, Rawahul Daruquthni. ${ }^{26}$

Dasar pertimbangan Majelis Hakim dalam mem-fasakh-kan perkawinan antara Pemohon dan Termohon yang disebabkan karena Termohon mengalami gangguan jiwa atau stres dalam Putusan Nomor 1899/Pdt.G/2013/PA.Pt. untuk seluruhnya berdasar pada dasar faktual, dasar hukum, dan Majelis Hakim sependapat dan mengambil alih pendapat ahli fiqh. Dasar faktual yaitu berdasar fakta-fakta yang didapat didalam persidangan yaitu berdasar pada dalil-dalil permohonan pemohon, alat bukti, dan keterangan saksi dipersidangan. Dasar hukum Majelis Hakim dalam mem-fasakh-kan perkawinan antara Pemohon dan Termohon diantaranya seperti Undang-Undang Nomor 1 Tahun 1974, Peraturan Pemerintah Nomor 9 Tahun 1975, Kompilasi Hukum Islam, dan Al-Qur'an.

\section{G. Penutup}

\section{Simpulan}

Dari hasil dan penelitian diatas dapat disimpulkan bahwa:

1. Fasakh perkawinan dalam Putusan Nomor 1899/Pdt.G/2013/PA.Pt di Pengadilan Agama Pati dalam perkara permohonan fasakh yang diajukan Pemohon terhadap Termohon yang disebabkan karena Termohon mengalami gangguan jiwa atau stres, merupakan alasan-alasan perceraian. Majelis Hakim dalam mem-fasakh-kan perkawinan antara Pemohon dan Termohon karena rumah tangga antara Pemohon dan Termohon merupakan rumah tangga yang berantakan, sudah tidak harmonis dan tidak mencapai tujuan perkawinan sebagaimana yang terdapat dalam Undang-Undang Nomor 1 Tahun 1974 tentang Perkawinan, dan telah terdapat alasan untuk bercerai sebagaimana yang dimaksud dalam Pasal 19 huruf (e) Peraturan Pemerintah Nomor 9 Tahun 1975 juncto Pasal 116 huruf (e) Kompilasi Hukum Islam yaitu perceraian dapat terjadi karena alasan-alasan: salah satu pihak mendapat cacat badan atau penyakit dengan akibat tidak dapat menjalankan kewajibannya sebagai suami istri sehingga perkawinan antara Pemohon dan Termohon dapat difasakhkan dan Pemohon

\footnotetext{
${ }^{25}$ Ibid.,

${ }^{26}$ Ibid., halaman 137.
} 
didalam persidangan telah dapat membuktikan kebenaran dalil-dalil permohonannya, dan permohonan Pemohon tidak melawan hukum.

2. Dasar pertimbangan Hakim dalam Putusan Nomor 1899/Pdt.G/2013/PA.Pt dalam memfasakh-kan perkawinan antara Pemohon dan Termohon yaitu berdasarkan dasar faktual, dasar hukum dan Majelis Hakim sependapat dan mengambil alih pendapat ahli fiqh. Dasar faktual yaitu berdasar fakta-fakta yang didapat didalam persidangan yaitu berdasar pada dalil-dalil permohonan Pemohon, alat bukti, dan keterangan saksi dipersidangan. Dasar hukum Majelis Hakim dalam mem-fasakh-kan perkawinan antara Pemohon dan Termohon diantaranya seperti Undang-Undang Nomor 1 Tahun 1974, Peraturan Pemerintah Nomor 9 Tahun 1975, Kompilasi Hukum Islam, dan Al-Qur'an. Dan Majelis Hakim sependapat dan mengambil alih pendapat ahli fiqh. Dengan difasakhkannya perkawinan antara Pemohon dan Termohon oleh Majelis Hakim dalam Putusan Pengadilan Agama Pati Nomor 1899/Pdt.G/2013/PA.Pt maka seketika itu juga bubarlah perkawinan tersebut, dan mereka sudah tidak lagi berkedudukan sebagai suami istri.

\section{Saran}

Berdasarkan simpulan tersebut, Penulis memberikan saran sebagai berikut:

1. Majelis Hakim dalam mem-fasakh-kan perkawinan antara Pemohon dan Termohon karena Termohon mengalami gangguan jiwa atau stres yang harus dibuktikan di dalam persidangan, menurut Peneliti pembuktian cacat badan atau penyakit yang ada pada Termohon, Majelis Hakim hendaknya tidak hanya berdasarkan pada saksi-saksi yang dihadirkan Pemohon, tetapi harus dibuktikan dengan alat bukti pendukung lain seperti surat keterangan dari Rumah Sakit Jiwa.

2. Seseorang yang akan melangsungkan perkawinan, hendaknya harus lebih berhati-hati dalam memilih pasangan yang akan dinikahinya, sebelum perkawinan itu dilakukan, hendaknya antar calon pengantin laki-laki maupun perempuan lebih mengenal satu sama lain agar dapat mengetahui kepribadian masing-masing calon pengantin, apakah calon istri atau calon suami yang akan kita nikahi dalam keadaan sehat, tidak mengalami gangguan jiwa atau stres sehingga terhindar dari perceraian karena ketidaktahuan kondisi calon istri/suami.

\section{DAFTAR PUSTAKA}

\section{a. Buku-Buku}

Ali, Zainuddin. Metode Penelitian Hukum. Sinar Grafika: Jakarta, 2010.

Fuady, Munir. Konsep Hukum Perdata. Jakarta: Rajawali Pers, 2014.

Nuruddin, Amiur Dan Azhari Akmal Tarigan. Hukum Perdata Islam di Indonesia: Studi Kritis Perkembangan Hukum Islam dari Fikih, UU No.1/1974 Sampai KHI. Jakarta: Kencana, 2004.

Syaifuddin, Muhammad, Sri Turatmiyah, dan Annalisa Yahanan. Hukum Perceraian. Jakarta: Sinar Grafika, 2014. 
Syarifuddin, Amir. Hukum Perkawinan Islam di Indonesia: Antara Fiqh Munakahat dan Undang-Undang Perkawinan. Jakarta: Kencana, 2006.

Usman, Rachmadi. Aspek-Aspek Hukum Perorangan \& Kekeluargaan di Indonesia. Jakarta: Sinar Grafika, 2006.

\section{b. Peraturan Perundang-undangan}

Undang-Undang Nomor 1 Tahun 1974 tentang Perkawinan.

Undang-Undang Nomor 50 Tahun 2009 tentang perubahan kedua atas Undang-Undang Nomor 7 Tahun 1989 tentang Peradilan Agama.

Instruksi Presiden Nomor 1 Tahun 1991 Tentang Kompilasi Hukum Islam.

c. Jurnal

Suhaimi, "Gangguan Jiwa Dalam Perspektif Kesehatan Mental Islam". Jurnal RISALAH (online),Vol.26,No.4,(https://media.neliti.com/media/publications/127638-IDgangguan-jiwa-dalam-perspektif-kesehatan.pdf, diakses 10 November 2017).

\section{d. Skripsi}

Wirza Desianty, Ellida. "Analisis Putusan Hakim Pengadilan Agama Makassar Mengenai Fasakh Perkawinan Karena Murtad (Studi Kasus Putusan Pengadilan Agama Makassar Nomor 152/Pdt.G/2012/PA Mks)". Skripsi Fakultas Hukum, Universitas Hasanuddin Makassar, 2013. 